\title{
PELATIHAN DAN PENDAMPINGAN DEMO INSTRUMENTASI BAGI MAHASISWA SEBAGAI BAGIAN GOOD LABORATORY PRACTICE
}

\author{
Dhony Hermanto1), Nurul Ismillayli1), Ulul Khairi Zuryati²), Ruru Honiar²), Baiq Mariana²), \\ I G. Ayu Sri Andayani²) \\ 1)Program Studi Kimia, Fakultas Matematika dan IImu Pengetahuan Alam, Universitas Mataram, \\ Mataram, NTB, Indonesia \\ 2)Laboratorium Kimia Analitik, Fakultas Matematika dan IImu Pengetahuan Alam, Universitas Mataram, \\ Mataram, NTB, Indonesia \\ Corresponding author: Nurul Ismillayli \\ E-mail : nurul.ismillayli@unram.ac.id
}

Diterima Juli 2021, Disetujui Agustus 2021

\begin{abstract}
ABSTRAK
Laboratorium kimia merupakan salah satu jenis laboratorium yang memiliki resiko sangat berbahaya dalam penyelenggaraan pendidikan, penelitian dan/atau pengabdian kepada masyarakat, sehingga laboratorium harus dikelola dan digunakan secara baik dan bijaksana. Pengoperasian peralatan sebagai salah satu aktivitas Good Laboratory Practice (GLP) merupakan aktivitas secara rutin dilakukan di laboratorium kimia. GLP dapat mewujudkan keselamatan kerja di laboratorium dan meminimalisir kerusakan peralatan akibat kesalahan operasi dan pemeliharaan instrumen. Kegiatan pengabdian ini adalah demo peralatan/instrumentasi Laboratorium Kimia Analitik FMIPA-Universitas Mataram. Metode kegiatan yang dilakukan yaitu pelatihan dan pendampingan yang berupa demo peralatan/instrumentasi meliputi kromatografi gas-spektroskopi massa (GC-MS), kromatografi cair kinerja tinggi (KCKT), spektrometer serapan atom (SSA) dan infra merah (FTIR). Kegiatan ini dilakukan untuk meningkatkan keterampilan dasar mitra dalam pengoperasian instrumentasi tersebut. Mitra kegiatan adalah 20 mahasiswa program studi Kimia semester lanjut (5-8). Keberhasilan kegiatan diukur dengan membandingkan skor tes mitra sebelum dan setelah kegiatan dilakukan. Kegiatan pengabdian berlangsung baik dan menghasilkan peningkatan pemahaman serta keterampilan mitra dalam mengoperasikan instrumen yang ditunjukkan dengan peningkatan skor tes mitra. Kegiatan ini diharapkan dapat mewujudkan GLP sehingga kegiatan penelitian dilakukan dengan aman dan efisien.
\end{abstract}

Kata kunci: pelatihan; instrumen; good laboratory practise; mahasiswa.

\begin{abstract}
Chemical laboratory is one type of laboratory that has a very dangerous risk in the implementation of education, research and/or community service, so the laboratory must be managed and used properly and wisely. Equipment operation as one of the Good Laboratory Practice (GLP) activities is a routine activity carried out in chemical laboratory. GLP could realize work safety in laboratory and minimize instrument operation and maintenance mistake This community service activity was a demonstration of instrumentation of the Analytical Chemistry Laboratory, FMIPA-University of Mataram. The method of activity carried out are training and assistance in form of instrument demo including gas chromatography-mass spectroscopy (GC-MS), high performance liquid chromatography (HPLC or HPLC), atomic absorption spectrometer (SSA or AAS) and infrared spectrometer (FTIR). This activity is carried to improve basic skill of partner in operating of instruments. The activity partners are 20 students of the advanced semester (5-8 ${ }^{\text {th }}$ semester) in Departement of Chemistry. The success of activity was measured by comparing the partner's test score before and after the activity was carried out. The service activity went well and could increase the partners' understanding and skills in operating the instrument. This activity is expected to realize the GLP so that research activities are carried out safely and efficiently.
\end{abstract}

Keywords: training; instrument; good laboratory practice; student.

\section{PENDAHULUAN}

Kegiatan pembelajaran yang efektif perlu didukung oleh sarana dan prasarana yang memadai, salah satunya yang dapat menunjang keterampilan mahasiswa adalah laboratorium (Suryanta, 2010; Subamia, 2012).
Laboratorium pendidikan merupakan unit penunjang akademik pada lembaga pendidikan untuk kegiatan pengujian, kalibrasi, dan/atau produksi dalam skala terbatas, dengan menggunakan peralatan dan bahan berdasarkan metode keilmuan tertentu, dalam 
rangka pelaksanaan tridarma perguruan tinggi yang meliputi pendidikan, penelitian, dan/atau pengabdian kepada masyarakat (Permenpan RB No. 03, 2010). Laboratorium pendidikan dikelompokkan menjadi 4 tipe antara lain: 1) laboratorium tipe I yaitu laboratorium ilmu dasar yang terdapat di sekolah pada jenjang pendidikan menengah; 2) laboratorium tipe II yaitu laboratorium ilmu dasar yang terdapat di perguruan tinggi tingkat persiapan; 3) laboratorium tipe III yaitu laboratorium bidang keilmuan terdapat di jurusan atau program studi pada perguruan tinggi; dan 4) laboratorium tipe IV yaitu laboratorium terpadu yang terdapat di pusat studi fakultas atau universitas.

Kegiatan pendidikan di laboratorium pada umumnya tidak terlepas dari kegiatan pengamatan dan pengukuran (Lestari et al., 2017). Kemampuan pengguna laboratorium dalam menggunakan alat ukur yang memiliki karakteristik masing-masing yang membutuhkan keterampilan tertentu dari praktikan (Pujianto, 2011; Koretsky et al., 2011). Peralatan laboratorium dibagi 3 kategori antara lain: 1) Peralatan kategori 3 yaitu peralatan laboratorium dengan cara pengoperasian dan perawatannya sulit, risiko penggunaan tinggi, akurasi/kecermatan pengukurannya tinggi, serta sistem kerja rumit sehingga pengoperasiannya memerlukan pelatihan khusus/tertentu dan bersertifikat; 2) Peralatan kategori 2 yaitu peralatan laboratorium dengan cara pengoperasian dan perawatannya sedang, risiko penggunaan sedang, akurasi/kecermatan pengukurannya sedang, serta sistem kerja yang tidak begitu rumit, akan tetapi pengoperasiannya memerlukan pelatihan khusus/tertentu; 3) Peralatan kategori 1 yaitu peralatan laboratorium dengan cara pengoperasian dan perawatannya mudah, risiko penggunaan rendah, akurasi/kecermatan pengukurannya rendah, serta sistem kerja sederhana sehingga pengoperasiannya cukup menggunakan panduan (Permenpan RB No. 03, 2010). Laboratorium yang merupakan tempat bagi mahasiswa untuk belajar mengamati, mempraktekkan dan membuktikan teori yang dipelajari di kelas, namun demikian mahasiswa dalam kegiatan praktikum di laboratorium umumnya hanya dapat menggunakan peralatan kategori 1 dan 2. Peralatan kategori 3 yang ada pada laboratorium kategori IV dioperasikan oleh teknisi/laboran yang sekarang dikenal sebagai Pranata Laboratorium Pendidikan (PLP) (Vendamawan, 2015; Raharjo, 2017).

Good Laboratory Practice, GLP adalah suatu metode penyelenggaraan laboratorium yang melakukan pengujian, instalasi, pekerjaan dan kondisi, pelaksanaan, pemantauan, pencatatan dan pelaporan pengujian sesuai dengan standar nasional/internasional untuk memenuhi persyaratan keselamatan yang berlaku dan persyaratan sanitasi (Angga, 2005). GLP merupakan kegiatan guna mengatasi kekurangan pada penguasaan keterampilan dalam pengoperasian peralatan laboratorium bagi mahasiswa (Ujianti et al., 2017). GLP yang ditawarkan pada mahasiswa kimia tingkat lanjut berupa pelatihan dan pendampingan yang berupa demo peralatan/instrumentasi laboratorium kimia kategori 3 yang dilaksanakan di Laboratorium Kimia Analitik FMIPA-Universitas Mataram. Instrumen kimia tersebut antara lain kromatografi gasspektroskopi massa (GC-MS), kromatografi cair kinerja tinggi (KCKT atau HPLC), spektrometri serapan atom (SSA atau AAS), dan spektrometri infra merah (FTIR).

\section{METODE PELAKSANAAN Kerangka Pemecahan Masalah}

Kegiatan pengabdian dilakukan di Laboratorium Kimia Analitik FMIPA-Universitas Mataram pada tanggal 2-3 Juni 2021 dengan melibatkan mitra sebanyak 20 mahasiswa Program Studi Kimia FMIPA Universitas Mataram yang telah berada di semester lanjut (5-8). Pada semester 5 ke atas mahasiswa telah mendapatkan teori tentang instrumentasi kimia yang menjadi objek pelatihan. Masalah pokok yang akan dipecahkan dalam pengabdian kepada masyarakat ini berkaitan dengan rendahnya kompetensi mahasiswa kimia dalam pengoperasian instrumentasi laboratorium kimia. Minimnya kesempatan menggunakan keterampilan dasar dalam pengoperasian instrumentasi laboratorium kimia kategori 3, solusi yang diambil untuk memecahkan permasalahan tersebut adalah kegiatan GLP melalui pelatihan dan pendampingan yang berupa demo peralatan/instrumentasi. Pelatihan juga mencakup diskusi untuk meningkatan pemahaman mahasiswa tentang aspek-aspek kompetensi yang dimilki oleh lulusan sarjana kimia.

\section{Realisasi Pemecahan Masalah}

Realisasi kegiatan pengabdian kepada masyarakat ini dimulai dengan penjajagan dan sosialisasi khalayak sasaran untuk minginformasikan program dan waktu pelaksanaan kegiatan. Selanjutnya, ditindak lanjuti dengan pelaksanaan kegiatan in servis pada tanggal 02 Juni 2021. Kegiatan pelatihan dan pendampingan berlangsung di Laboratorium Kimia Analitik, FMIPAUniversitas Mataram (merupakan laboratorium tipe IV) berupa ceramah, diskusi dan demo 
peralatan/instrumentasi kimia. Narasumber pada kegiatan ini antara lain Dr. Dhony Hermanto (selaku kepala laboratorium) dan rekan dosen Nurul Ismillayli (sebagai pendamping pada kegiatan ceramah dan diskusi) serta dibantu tenaga PLP antara lain Ulul Khairi Zuryati (sebagai pendamping pada instrument HPLC) Ruru Honiar (sebagai pendamping pada instrument GC-MS), Baiq Mariana (sebagai pendamping pada instrument spektrofotometer AAS), dan I Gusti Ayu Sri Andayani (sebagai pendamping pada instrument spektrometer FTIR).

\section{Khalayak Sasaran}

Khalayak yang dijadikan sasaran kegiatan ini adalah mahasiswa kimia tingkat lanjut yang nantinya akan melaksanakan tugas akhir. Peserta yang dilibatkan diharapkan dapat mengimbas kepada mahasiswa lain.

\section{Metode yang Digunakan}

Metode yang digunakan untuk mencapai tujuan adalah metode ceramah/diskusi dan praktek (demo/simulasi). Gabungan kedua metode tersebut diharapkan mampu meningkatkan pemahaman dan keterampilan khalayak berkaitan dengan keterampilan mengoperasikan instrumen kimia di laboratorium. Kegiatan ceramah dan diskusi dilakukan untuk memberikan pemahaman peserta tentang GLP yang bertujuan untuk meningkatkan pengetahuan tentang instrumentasi kimia di laboratorium (Tawfik, 2008; Emda, 2017). Kegiatan praktek merupakan lanjutan dari ceramah dan diskusi yang secara khusus bertujuan untuk meningkatkan keterampilan peserta dalam menggunakan instrument kimia di laboratorium yang diisi dengan demo (simulasi) masingmasing instrument yang dibimbing oleh narasumber sesuai bidang keahliannya.

\section{Evaluasi Kegiatan}

Evaluasi kegiatan dilakukan terhadap proses dan output kegiatan. Evaluasi proses berkaitan dengan kehadiran peserta, semangat mengikuti kegiatan, dan evaluasi kinerja keterampilan mengoperasikan instrument kimia di laboratorium. Evaluasi proses dilakukan selama kegiatan berlangsung. Evaluasi output dilakukan terhadap penguasaan pengetahuan dan keterampilan peserta. Pelaksanaan program kegiatan pengabdian kepada masyarakat ini dinyatakan berhasil jika hasil evaluasi proses dan output minimal bernilai baik.

\section{HASIL DAN PEMBAHASAN}

Kegiatan pengabdian kepada masyarakat oleh Tim Laboratorium Kimia
Analitik FMIPA-Universitas Mataram (Gambar 1) dengan khalayak sasaran mahasiswa kimia tingkat lanjut. Peserta pelatiahan dan pendampingan (GLP) diharapkan memiliki keterampilan dalam mengoperasikan instrumen kimia di laboratorium. Kegiatan diawali dengan penjelasan prinsip dasar pengukuran menggunakan instrumen GC-MS, HPLC, AAS dan FTIR serta bagian-bagian dari instrumen tersebut. Tahapan berikutnya adalah demo pengukuran dan pengukuran sampel oleh mitra. Tahapan terakhir adalah evaluasi untuk mengukur tingkat kepahaman mitra.

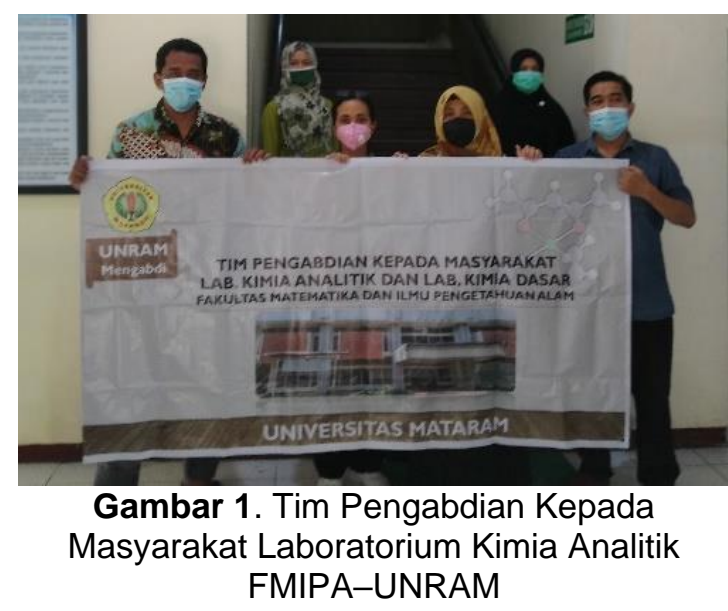

Kegiatan ceramah dan diskusi yang telah dilaksanakan bertujuan untuk meningkatkan pemahaman peserta terhadap kompetensi dasar yang dipersyaratkan yang harus dimiliki dalam mengoperasikan peralatan laboratorium. Diskusi diawali dengan penyajian makalah oleh para narasumber pelatihan. Materi ceramah mencakup beberapa kompetensi dasar instrumentasi kimia antara lain: diskripsi alat, prinsip dasar dan prinsip kerja, skema alat dan aplikasi. Setiap instrumen mempunyai buku petunjuk atau keterangan penggunaan yang berisi informasi tentang petunjuk penggunaan alat dan petunjuk pemeliharaannya.

Hasil ceramah dan diskusi yang telah dilakukan pada bagian pertama kegiatan pengabdian kepada masyarakat ini dapat dirumuskan sebagai berikut. 1) Secara umum kegiatan ceramah dan diskusi berlangsung sangat baik. Antusiasme peserta pada tahap ini ditunjukkan dengan kesungguhan dalam mengikuti sesi sajian materi pelatihan yang disajikan oleh narasumber dan banyaknya pertanyaan yang diajukan terkait prinsip dan fungsi serta cara kerja berbagai jenis instrumantasi kimia yang terdapat di laboratorium. Banyaknya pertanyaan yang muncul dari peserta menunjukkan adanya respon positif dari peserta terhadap materi pelatihan dan banyak hal yang masih perlu 
diketahui terkait dengan keterampilan dasar pengoperasian alat kimia di laboratorium. 2) Hal lain yang dapat disimpulkan dari kegiatan diskusi adalah pengetahuan awal peserta tentang pengoperasian instrumentasi kimia di laboratorium relatif masih kurang terutama alatalat kategori 3. Namun, setelah diberikan pemaparan materi, tingkat pemahaman peserta pelatihan menunjukkan hasil yang baik. Hal ini diindikasikan dengan perbandingan skor test sebelum dan setelah pelatihan dilaksanakan, seperti ditampilkan pada Gambar 2.

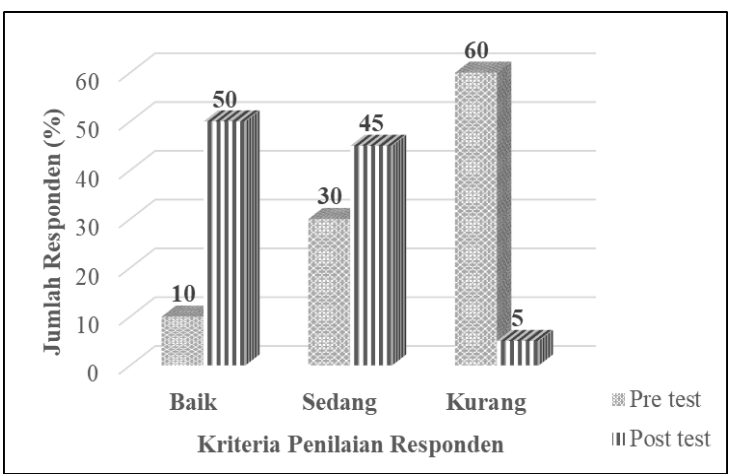

Gambar 2. Perbandingan Skor Tes Sebelum dan Setelah Kegiatan Pengabdian Kepada Masayarakat

Berdasarkan Gambar 2 terjadi peningkatan kepemahaman mitra dalam pengetahuan dan keterampilan mengoperasikan alat. Hal ini ditunjukkan dengan peningkatan skor tes mitra setelah kegiatan pelatihan dilakukan.

Kegiatan pendampingan GLP mengenai keterampilan dasar mengggunakan alat-alat laboratorium dilakukan pada hari terakhir sesion kegiatan praktek. Kegiatan ini melipui demo pengukuran sample menggunakan GC-MS, HPLC, AAS dan spektrometer FTIR. Beberapa PLP memberikan contoh pengoperasian instrumen dan dilanjutkan dengan uji coba oleh beberapa mahasiswa. Kegiatan demo dilakukan secara berkelompok dimulai dengan preparasi sampel, pengukuran, analisis dan interpretasi data, seperti ditunjukkan pada Gambar 3.

Kegiatan demo berlangsung baik dan menghasilkan peningkatan pemahaman serta keterampilan mitra dalam mengoperasikan instrumen kimia. Hal ini dibuktikan dengan berhasilnya pengukuran sampel oleh mitra dengan menggunakan instrumen tersebut.

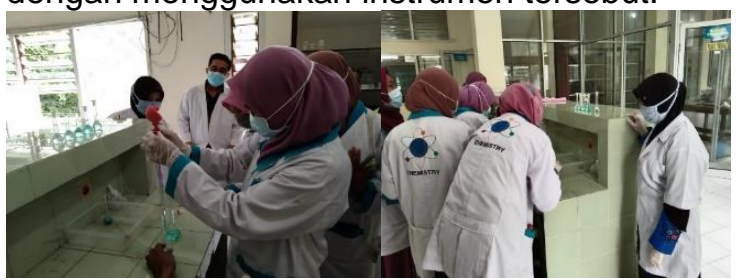

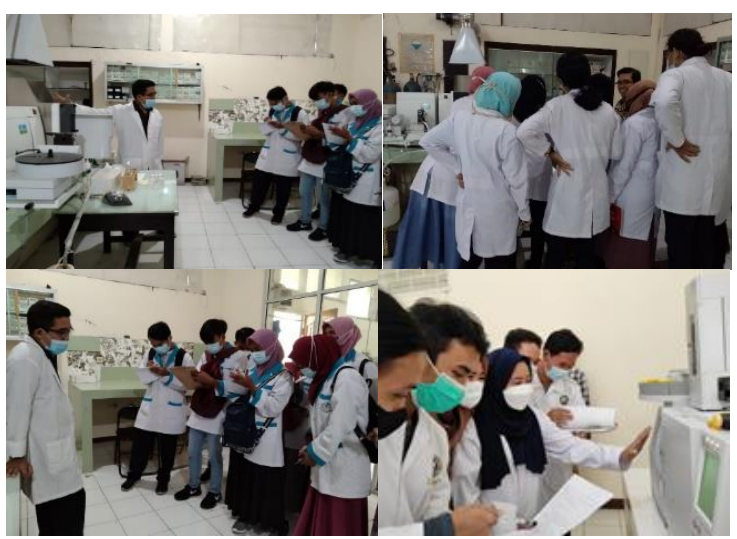

Gambar 3. Demo Pengukuran Sampel

Menggunakan Instrumen GC-MS, HPLC, AAS dan Spektrometer FTIR

Kendala kegiatan pengabdian kepada masyarakat pelatihan dan pendampingan demo instrumentasi adalah kondisi pandemi Covid-19 yang membatasi jumlah peserta kegiatan dan durasi pelaksanaan kegiatan. Kendala dapat diatasi dengan membagi mitra dalam beberapa kelompok kecil dan melaksanakan kegiatan dengan sistem shift/bergliran. Selain itu, penerapan protokol kesehatan standar saat pandemi juga diterapkan. Keberhasilan kegiatan pengabdian diharapkan dapat menjadi pengalaman pra-profesional mereka dalam menerapkan GLP.

\section{SIMPULAN}

Kegiatan pengabdian kepada masyarakat berupa pelatihan dan pendampingan pengoperasian alat berupa GSMS, HPLC, AAS dan spektrometer FTIR bagi mahasiswa Program Studi Kimia telah berlangsung dengan baik. Hasil kegiatan berupa peningkatan pengetahuan dan keterampilan mitra tentang pengoperasian alat. Kegiatan ini diharapkan dapat mewujudkan GLP sehingga kegiatan penelitian di laboratorium dapat dilakukan dengan aman dan efisien.

\section{UCAPAN TERIMA KASIH}

Penulis sampaikan terima kasih kepada para pendamping mitra (co-asisten) yang berkontribusi pada pelaksanaan kegiatan pengabdian kepada masyarakat tentang pelatihan dan pendampingan demo instrumentasi bagi mahasiswa sebagai bagian GLP.

\section{DAFTAR RUJUKAN}

Angga. (2005). Manajemen Laboratorium: Praktek Laboratorium yang Baik (II), Good Laboratory Practise. Warta Kimia Analitik, 11(15), 30-32. 
Emda, A. (2017). Laboratorium Sebagai Sarana Pembelajaran Kimia dalam Meningkatkan Pengetahuan dan Ketrampilan Kerja IImiah. Lantanida Journal, 5(1), 1-10.

Koretsky, M., Kelly, C., Gummer,E. (2011). Student Perceptions of Learning in the Laboratory: Comparison of Industrially Situated Virtual Laboratories to Capstone Physical Laboratories. Journal of Engineering Education, 100(3), 540-573.

Lestari, N. A., Jauhariyah, M. N. R., Deta, U. A. (2017). Pelatihan Manajemen Laboratorium untuk Pengelola Laboratorium IPA Tingkat SMA Di Kabupaten Bojonegoro. Jurnal Abdi, 3(1), 17-21.

Peraturan Menteri Negara Pendayagunaan Aparatur Negara dan Reformasi Birokrasi, Permenpan RB No. 3 (2010), Tentang Jabatan Fungsional. Pranata Laboratorium Pendidikan Dan Angka Kreditnya. Jakarta: Kementrian Pendayagunaan Aparatur Negara dan Reformasi Birokrasi.

Pujianto. 2011. Manajemen Pengelolaan Laboratorium IPA dan Cara Pengelolaannya. Yogyakarta: UNY.

Raharjo. (2017). Pengelolaan Alat Bahan dan Laboratorium Kimia. Jurnal Kimia Sains dan Aplikasi, 20(2), 99-104.

Sanjaya, W. (2010). Kurikulum dan Pembelajaran. Teori dan Praktek KTSP. Jakarta: Kencana.

Subamia, I. D. P (2012). Pelatihan Keterampilan Dasar Laboratorium (Basic Laboratory Skill) Bagi Staf Laboratorium IPA SMP Se-Kabupaten Buleleng. Jurnal Widya Laksana, 1(2), 36-48.

Suryanta. (2010). Manajemen Operasional Laboratorium. Yogyakarta: UNY

Tawfik, A. S. (2008). Pre-laboratory Visualisation Techniques to support Learning and Teaching of Introductory Chemistry Laboratory. Chemical Education Journal, 12(1), 1-5.

Ujianti, R., Nurdyansyah, F., Umiyati, R., Supriyadi, B., Widyastuti, D. A. (2017). Optimalisasi Performa Laboratorium Melalui GLP (Good Laboratory Practise) dan K3 (Keamanan dan Keselamatan Kerja). Prosiding Seminar Nasional Sains dan Entrepreneurship IV, Universitas PGRI Semarang.

Vendamawan, R. (2015). Pengelolaan Laboratorium Kimia. Jurnal Metana, 12(1), 41-46. 